$88,8 \mathrm{~m}$ e $10 \mathrm{Km}$ distante do centro urbano e temperatura anual média de $28^{\circ} \mathrm{C}$. E no Alto da Cruz, situada na zona urbana do município de Baturité, na latitude $4^{\circ} 19^{\prime} \mathrm{S}$, longitude $38^{\circ} 53^{\prime}$ 'O, altitude $175 \mathrm{~m}$ e temperatura anual média de $26^{\circ} \mathrm{C}$.

Nas duas comunidades foram realizadas entrevistas com questionário estruturado complementado com conversas informais para conhecer como são utilizadas as plantas medicinais, seus nomes populares, partes usadas, modo de preparo e indicação e como são repassados os saberes entre as gerações. Foram entrevistadas 21 famílias residentes nem cada comunidade.

Os dados coletados foram analisados no programa SYSTAT e realizada uma análise descritiva, calculando medidas de tendência central (média e mediana), frequências e porcentagens de ocorrência, consoante o indicador avaliado. Correlações entre variáveis foram analisadas pelo coeficiente de correlação de Spearman e o teste não paramétrico de Mann-Whitney, apropriado para amostras de dimensões reduzidas, para comparar os valores obtidos no estudo a um nível de confiança de 0,05 .

\section{Resultados e Discussões}

As famílias da Brenha descendem dos habitantes da região desde o início do século XIX e, são constituídas na maioria por idosos, pois os jovens migraram para os grandes centros urbanos. Segundo Badke et al. (2012) as pessoas mais idosas possuem um maior conhecimento sobre o uso e indicações das plantas medicinais na saúde das comunidades rurais, que foram adquiridas ao passar dos anos, pela transferência dos saberes de uma geração para a seguinte, ou pela suas próprias vivências e observações. Das vinte e uma famílias entrevistadas, todas conhecem e utilizam as plantas medicinais, cultivadas em canteiros ou vasos ao redor das casas em quintais, hortas e pequenos roçados. As espécies encontradas com maior frequência foram o capim santo, utilizado para acalmar e a hortelã, para favorecer a digestão. As partes das plantas mais usadas no preparo dos remédios caseiros foram as folhas (16), seguido da casca (2), raiz (1), flores (1) e fruto (1). A maioria dos trabalhos envolvendo plantas medicinais destaca as folhas como o órgão mais utilizado no preparo de remédios (PINTO et al., 2006; MERHY \& SANTOS, 2017). Essa predominância das folhas pode ser atribuída a maior facilidade de coleta e disponibilidade durante todo o ano (PEREIRA et al., 2005). É importante observar que a maioria dos compostos ativos é encontrada nas folhas e sua coleta não causa muitos danos a planta, permitindo a sua preservação e continuo uso (Santos et al., 2015). A infusão (11) foi o modo de uso mais frequente de preparo dos remédios caseiros das plantas medicinais, seguido do chá (5), cataplasma (2), garrafada (2), lambedor (1), . Em outras comunidades 
amazônicas também foi observado que doenças internas são tratadas principalmente através do preparo

Na comunidade urbana Alto da Cruz, todas as famílias utilizam plantas medicinais, cultivadas ao redor das casas em quintais e algumas compradas. 21 famílias citaram a camomila (Matricaria chamomilla) para problemas gastrointestinais e calmante; 15 citaram erva cidreira (Melissa officinalis) como calmante; 14 o mastruz (Dysphania ambrosioides) para fratura; 9 a hortelã,(Mentha villosa) para problemas gastrointestinais e canela (cinnamomum) para dor muscular; 6 citaram alfavaca (Ocimum gratissimum) para gripes, malvarisco (Plectranthus ambroinicus) para inflamações e eucalipto (Eucalyptus glubulusLabill) para resfriados; 5 o capim santo (Cymbopogon citratus) como calmante e mussambê (Cleome spinosa L.) para bronquite; 4 a sena (Senna alexandrina) para prisão de ventre , já pepaconha, jatobá,(Hymenaea) e aroeira (Astronium urundeuva) como cicatrizantes; 3 a casca de laranja (Citrus $X$ sinensis) para digestão, casca de romã (Punica granatum) para inflamação da garganta, macela (Achyrocline satureioides) para gastrite e cumaru (Dipteryx odorata) para gripe e 2 famílias citaram a casca de ameixa (Ximenia americana) para inflamações.

\section{Conclusões}

As plantas medicinais são o meio de cura das enfermidades mais frequentes das comunidades necessitadas do maciço de Baturité, no estado do Ceará.

\section{Referências}

BADKE, M.R.; BUDÓ, M.L.D.; ALVIM, N.A.T.; ZANETTI, G.D.; HEISLER, E.V. Saberes e práticas populares de cuidado em saúde com o uso de plantas medicinais. Texto \& Contexto Enfermagem, v.21, n.2, p.363-370, 2012.

MERHY, T.S.M.; SANTOS, M.G. A Etnobotânica na escola: interagindo saberes no ensino fundamental. Revista Práxis, v.9, n.17, p.9-22, 2017.

PEREIRA, C.O.; LIMA, E.O.; OLIVEIRA, R. A.G.; TOLEDO, M.S.; AZEVEDO, A.K.A.; GUERRA, M.F.; PEREIRA, R.C. Abordagem etnobotânica de plantas medicinais utilizadas em dermatologia na cidade de João Pessoa-Paraíba, Brasil. Revista Brasileira de Plantas Medicinais, v.7, n.3, p.9-17, 2005.

PINTO, E.P.P. et al. Conhecimento popular sobre plantas medicinais em comunidades rurais de mata atlântica - Itacaré, BA, Brasil. Acta Botanica Brasilica, v.20, n.4, p.751-762, 2006

SANTOS, A.C.B.; NUNES, T.S.; COUTINHO, T.S.; SILVA, M.A.P. Uso popular de espécies medicinais da família Verbenaceae no Brasil. Rev. Bras. Pl. Med., Campinas, v.17, n.4, supl. II, p.980-991, 2015. 